\title{
Chapter 21 \\ The Overview and Legal Issues Regarding Real Estate Tech
}

\author{
Haruo Narimoto
}

\begin{abstract}
In this paper, I will introduce the types of real estate tech services already provided in Japan and give concrete examples, as well as explain the real estate crowdfunding, which is attracting particular attention, including laws and regulations. I will also discuss the legal issues in the use of data and personal information that are expected to arise in real estate tech services in the future.
\end{abstract}

Keywords Real Estate Tech · Prop Tech · Crowdfunding $\cdot$ ICT $\cdot$ AI $\cdot$ Real estate information

\subsection{Introduction}

As with FinTech, there are already many new services and companies in existence in the United States that are involved in Real Estate Tech, while various types of Real Estate Tech services and companies have also emerged in Japan, albeit belatedly. Nevertheless, as also with the case of FinTech, business models that are successful in the United States are not necessarily also appropriate for Japan as they are. Business models that take account of the features of the Japanese real estate market, the applicable legal systems, the customary practices and needs, as well as the national character need to be looked into.

\footnotetext{
H. Narimoto $(\bowtie)$

Attorney at Law, Tokyo, Japan

e-mail: hnarimoto@tmi.gr.jp 


\subsection{Types of Real Estate Tech Service in Japan}

\subsubsection{Matching Platform Service for Rentals, Sales, and Development}

1. The typical types are online matching services ${ }^{1}$ that mainly target individuals for transactions between sellers and buyers of real estate and leases between lessors and lessees. The strategies of many of these types appear to be to capture customers by offering fees that are lower than previous general levels or at no charge. There is a variety of services apart from simple sales and leases, such as matching services ${ }^{2}$ for people commissioning various contract works and contractors, matching services ${ }^{3}$ for current tenants who hope to vacate a so-called furnished property and prospective tenants who hope to move into a furnished property and matching services ${ }^{4}$ for sellers and buyers of land while proposing apartment management services to prospective buyers.

2. Concept of "intermediary"

A license is required ${ }^{5}$ under the Real Estate Brokerage Act to conduct the business of agency services or intermediary for the buying, selling, or leasing of building lots or buildings. On this point, the definition of "intermediation" is not prescribed in the Real Estate Brokerage Act. Legal precedent defines it as "any and all actual behavior made to conclude a contract for the buying, selling, exchanging, or leasing of building lots and buildings between relevant parties upon a request of one of the parties". 6

With regard to what type of behavior specifically corresponds to "intermediation," there is a view that it means "a behavior that results in the conclusion of a contract, for example, the search for transaction properties, the provision of property information, the advertising for sale, investigations such as the relationship of rights, local guiding, introduction of the contracting parties, explanation about the transaction property, etc., negotiation and adjustment of transaction terms, and witnessing the execution of the contract". 7 But even if there is a single behavior among those listed above that corresponds to the examples in this point of view, this does not immediately mean that it corresponds to "intermediation."

\footnotetext{
${ }^{1}$ There are trade matching services such as "Ouchi Direct" (https://realestate.yahoo.co.jp/direct) and "Kauru" (http://housmart.co.jp/). Rental matching services include "officee" (https://officee.jp/) and "nomad" (https://nomad-a.jp/).

2“"Tsukulink" (https://tsukulink.net/).

3“Tenpo ichiba" (https://tenpoichiba.jp/).

4"Tateru" (http://www.tateru.co/).

${ }^{5}$ Article 2, item (ii), Article 3, paragraph (1) of the Real Estate Brokerage Act.

${ }^{6}$ Tokyo High Court February 14, 2007 judgment (Tokyo High Court (Criminal matters) Hanketsu Jiho (Law Case Reports) Vol. 58, Items 1-12, page 7).

${ }^{7}$ Masaharu Okamoto and Misaki Uni "(Revised Edition) Point by point Explanation of the Real Estate Brokerage Act” (Taisei-Shuppan Co., Ltd., 2012) page 68.
} 
It is said that "the behavior of only providing selling and buying information in relation to residential land and building is simply an information-providing activity, and does not correspond to intermediation under Article 2, item (ii) of the Act unless there is negotiation or mediation for the conclusion of a contract between the relevant contracting parties". 8 There is a related administrative judgment that "the behavior of unqualified persons or 'Taneya' who receive an honorarium for providing information to such operators from the compensation received by such operators is not direct participation, so it does not correspond to a building lot and building business operator. If there is repeated behavior such as receiving independent fees from transactional behavior jointly conducted with an operator, such act may be recognized as being engaged as a building lot land and building business operator". "My personal opinion is that if the behavior is limited to simply providing or posting information (including the provision of information search function) and disseminating or exchanging information or the declaration of intent, it should not, in principle, be interpreted as corresponding to an "intermediation."

3. Shift to the use of IT for explanation of important matters

A social experiment of applying IT to the explanation of important matters in lease transactions and transaction between corporations ${ }^{10}$ was conducted up until the end of January 2017 in accordance with the "Final Report on the Investigative Committee Concerning the Approach to the Explanation of Important Matters using IT" dated January 30, 2015, and released by the Ministry of Land, Infrastructure, Transport and Tourism.

"A Report from the Investigating Committee Concerning the Social Experiment Relating to the Explanation of Important Matters Using IT" was released by the Ministry of Land, Infrastructure, Transport and Tourism in March 2017 taking account of the results of such trial experiment. This stated that it was appropriate to transition to full-fledged operations in FY2017 after implementing preparatory measures such as clarifying the items that should be observed when implementing the explanation of important matters using IT and notification to registered realestate brokers and concluded that the full-fledged operation of the explanation of important matters using IT pertaining to lease transactions should be started with a target date of October $2017 .^{11}$

\footnotetext{
${ }^{8}$ Masaharu Okamoto and Misaki Uni "(Revised Edition) Point by point Explanation of the Real Estate Brokerage Act” (Taisei-Shuppan Co., Ltd., 2012) pages 70 and 71.

${ }^{9}$ October 8, 1963 Construction Design No. 108, Response from the Director General of Planning, Ministry of Construction to the Director of Construction Department, Prefecture of Osaka.

${ }^{10}$ It is said to refer to the systems, etc. such as video conference and videophones that can engage in both video and voice simultaneously in both directions using PC, smartphone, tablets, etc.

${ }^{11}$ Note in regard to transactions between corporations, it was appropriate to continue the implementation of the social experiment, and that if there was no problem in taking the necessary measures and no new issues of concern emerge as a result of the verification by subsequent investing committees, there would be a transition to full-fledged operations. In addition, for purchase and sale transactions that include individuals, it was determined that there would be
} 
However, close attention has to be paid to the fact that the above operation will enable the use of IT to fulfill the obligation of explaining important matters, but it does not enable the issuance of documents mentioning important matters by electromagnetic means. Revision of the Real Estate Brokerage Act is likely to be required to make the issuance of the document explaining important matters itself possible.

\subsubsection{Real Estate Value Evaluation and Information Search Services}

1. These are the services that estimate and calculate the present value and sale price of real estate based on various open data and past transaction information for each company using independent algorithms and deep learning AI. ${ }^{12}$ Furthermore, there are also services that estimate and calculate the lease fees and future resale price when they are offered for lease and also services that provide information such as investment yields. ${ }^{13}$

2. Real estate appraisal business

"Real estate appraisal" is said to refer to the determination of the economic value of real estate, which is consequently indicated as price. ${ }^{14}$ On this point, although services that calculate the present price of real estate, for example, through AI, also seem to correspond to the service of real estate appraisal, since "real estate appraisal business" is set to mean the business of appraising real estate ${ }^{15}$ at the request of other people regardless of whether they do it themselves or use another person, determining or displaying the economic value of real estate without compensation would be possible to be considered not corresponding to "real estate appraisal business."

3. Real estate investment advisory business

Providing advices concerning sales and purchase of real estate as a business can be considered to correspond to a "real estate investment advisory business." However, this real estate investment advisory business is an optional registration system. ${ }^{16}$ Therefore, the approval and authorization of this real estate investment advisory business are not compulsory.

investigation by the investigating committee to verify the social experiment or full-fledged operations taking account of the status of implementation of full-fledged operations for lease transactions that commenced in FY2017 and the results of the investigation of the social experiment for transactions between corporations.

12،GEEO” (http://geeo.otani.co/), "Price Map" (http://www.homes.co.jp/price-map/), "IESHIL" (https://www.ieshil.com/), "Mansion Value" (https://mansionvalue.jp/), etc.

13“"Gate." (https://gate.estate/), "VALUE” (https://value.heyazine.com/) "How-ma" (https://www. how-ma.com/), etc.

${ }^{14}$ Article 2, paragraph (1) of the Act on Real Estate Appraising and Valuation.

${ }^{15}$ Article 2, paragraph (2) of the Act on Real Estate Appraising and Valuation.

16 “'Persons engaged in the real estate investment advisory business may be registered as General Real Estate Investment Advisory Business or a Comprehensive Real Estate Investment Advisory 


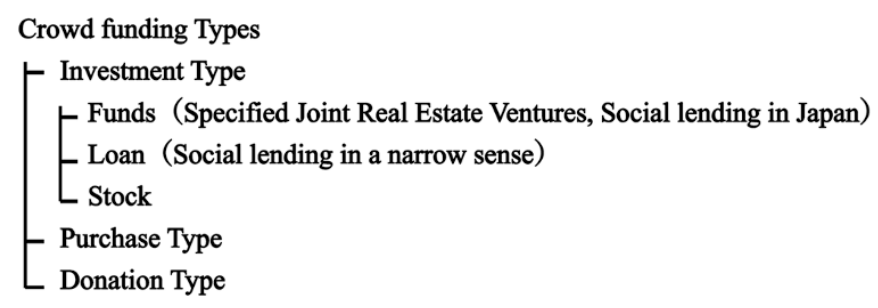

Fig. 21.1 Crowd Funding Types

\subsubsection{Crowd Funding}

"Crowd funding" is not something that is defined by law. Although there are definitions such as "schemes to link new and emerging companies with investors through internet sites to collect small amounts of funds from multiple investors," 17 in practice, there is wide scope not limited to "new and emerging companies" including the case of collecting funds for identified business projects and purposes and the solicitation of funds not for investment purposes. In the context of Real Estate Tech in this paper, it is used to mean something like "a scheme to offer or solicit fund contribution for investment in real estate in the form of small units from multiple investors using the internet (Fig. 21.1)."

\section{Specified Joint Real Estate Ventures}

An entity in a form that solicits investment by recruiting anonymous partnership (Tokumei-Kumiai) investment based on the Act on Specified Joint Real Estate Ventures ${ }^{18,19}$ (Fig. 21.2).

(i) Approval and authorization

If the business operator operates as a Specified Joint Real Estate Venture (so-called item (i) business) by receiving investment from investors in the

Business in the Real Estate Investment Advisory Business Register maintained by the Ministry of Land, Infrastructure, Transport and Tourism as prescribed by these regulations" (Article 3 of the Regulations for Registration as a Real Estate Investment Advisory Business).

${ }^{17}$ Page 2 of the "Report of the Working Group on the Provision of Risk Money to Emerging and Growing Companies of the Financial System Council" dated December 25, 2013.

${ }^{18}$ While this could theoretically also refer to Special Ventures that use so-called SPC (Article 2, paragraph (6) of the Act on Specified Joint Real Estate Ventures), at the present point in time there is no such subdivided products for individual investors that actually use Special Ventures. In addition, there are also multiple examples of voluntary partnership subdivided instruments, but this paper assumes general anonymous partnership (Tokumei-Kumiai) subdivided instruments. Note that in the case of anonymous partnership (Tokumei-Kumiai) subdivided instruments, almost all cases are through offering and solicitation via the actual business owner's own website ("Business owner" = "Platform provider").

19“"Surf Series" (http://www.sumitomo-rd.co.jp/fund/), "Mullion Bond" (https://www.mullion.co. jp/), “TATERU UNDING” (https://www.tateru-funding.jp/), etc. 


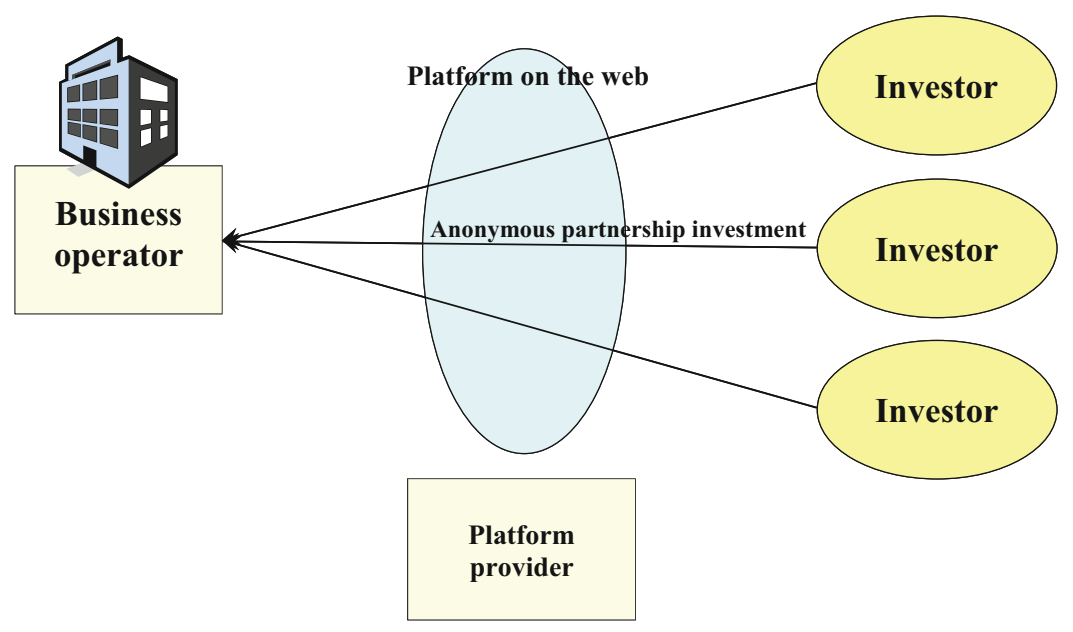

Fig. 21.2 Specified Joint Real Estate Ventures Structure

form of anonymous partnership (Tokumei-Kumiai) investment, and conducting real estate transactions such as sales and lease of real estate with such investment funds, then distributing the profit generated from such real estate transactions to investors, a permit needs to be obtained in accordance with the Act on Specified Joint Real Estate Ventures. There are requirements for a permit to be approved as an item (i) business such as capital requirements (100 million yen), a license under Building Lots and Building Transaction Business Act, and a requirement on personnel structure. Investment interests in anonymous partnership (Tokumei-Kumiai) pertaining to Specified Joint Real Estate Ventures (item (i) business) are excluded from being deemed securities under the Financial Instruments and Exchange Act, ${ }^{20}$ so business operators and platform providers do not have to be Type II Financial Instruments Business.

Note that the revised Act on Specified Joint Real Estate Ventures established in May 26, 2017, and promulgated on June 2 that year establishes a system for "Small Specified Joint Real Estate Ventures" with total investment below a certain level, and it is anticipated to mitigate the capital requirements for operating a Small Specified Joint Real Estate Venture. ${ }^{21}$

\footnotetext{
${ }^{20}$ Article 2, paragraph (2), item (v) c of the Financial Instruments and Exchange Act.

${ }^{21}$ The total investment amount and mitigated capital requirements for small business is scheduled to be specifically prescribed in governmental and ministerial ordinance to be introduced in future, but the Report of the Advisory Board on Real Estate Investment Market Policy, released on September 16, 2016, mentions that the "capital requirements are anticipated to be about 1000 million yen for both item (i) business operators and item (iii) business operators. Note that the revised Act is to be enacted within 6 months of the date of promulgation.
} 
(ii) Possibility of issuing documents via electromagnetic means

If aiming to execute a Specified Joint Real Estate Ventures contract pertaining to a Specified Joint Real Estate Ventures (item (i) business) (e.g., anonymous partnership (Tokumei-Kumiai) contract), there are provisions that require the delivery of documents that mention certain legal matters before the conclusion of the contract and at the time the contract is concluded. $^{22}$ However, the issuance of such documents solely through electromagnetic means on the Internet is not approved under existing laws.

On this point, in the draft revision of the Act on Specified Joint Real Estate Ventures referred to above in (1), it is planned to allow for provisions concerning procedures on the Internet for documents prior to the conclusion of the contract.

(iii) Number of people required for offering and solicitation

As mentioned in (1) above, anonymous partnership (Tokumei-Kumiai) investment interest pertaining to Specified Joint Real Estate Ventures (item (i) business) is excluded from being deemed securities under the Financial Instruments and Exchange Act, so disclosure regulations under the Financial Instruments and Exchange Act do not apply to the solicitation and offering of such anonymous partnership (Tokumei-Kumiai) investment interest. Therefore, even if there are more than 500 investors involved in the solicitation and offering of such anonymous partnership (Tokumei-Kumiai) investment interest, it will not correspond to "offering" (so-called public offering) under the Financial Instruments and Exchange Act, and there will be no obligation to create a securities registration statement, etc. In addition, the Act on Specified Joint Real Estate Ventures does not prescribe restrictions on matters such as the number of people for solicitation and offering or other disclosure regulations. This can be considered fit for crowd funding that collects small amounts of funds from multiple investors.

\section{Social lending 23}

Social lending is essentially the mediation of funds from lenders and borrowers through an internet platform, with funds solicited in the form of a cash consumer loan (Fig. 21.3), but in Japan it is highly likely that individual investors as lenders will need to register as money lenders under the Money Lending Business Act, so in practice, funds are currently solicited in the form of "an anonymous partnership (Tokumei-Kumiai) investment for a loan business conducted by a business operator," as shown in (Fig. 21.4). ${ }^{24}$

\footnotetext{
${ }^{22}$ Article 24 and Article 25 of the Act on Specified Joint Real Estate Ventures.

${ }^{23}$ Also referred to as P2P lending, or loan type crowd funding, etc.

${ }^{24} 24$ "LC Lending" (https://www.lclending.jp/) and "OwnersBook" (https://www.ownersbook.jp/) and others that target domestic real estate for collateral and "Gaia Funding" (https://www. gaiafunding.jp/ and others that target foreign real estate for collateral.
} 


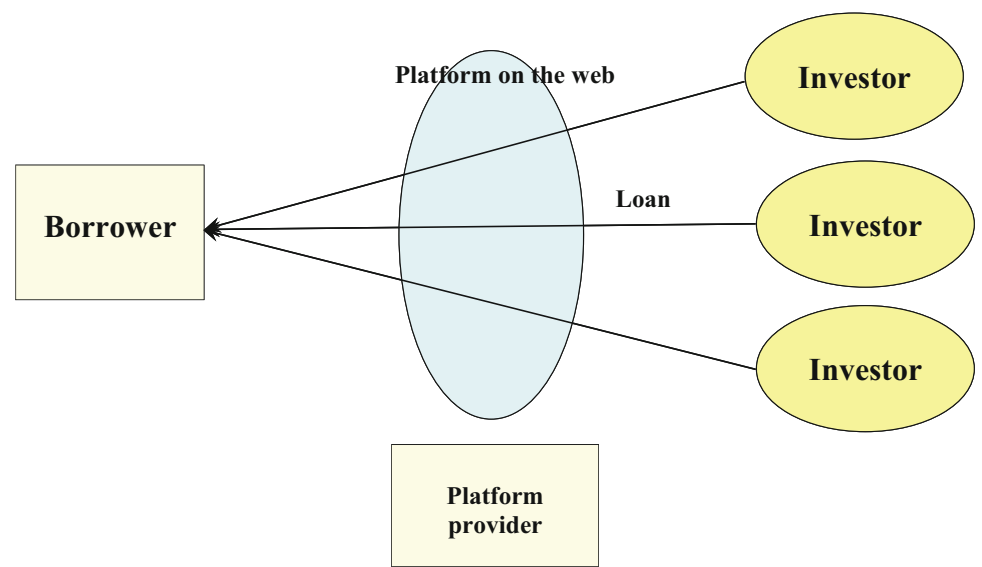

Fig. 21.3 Social Lending Structure

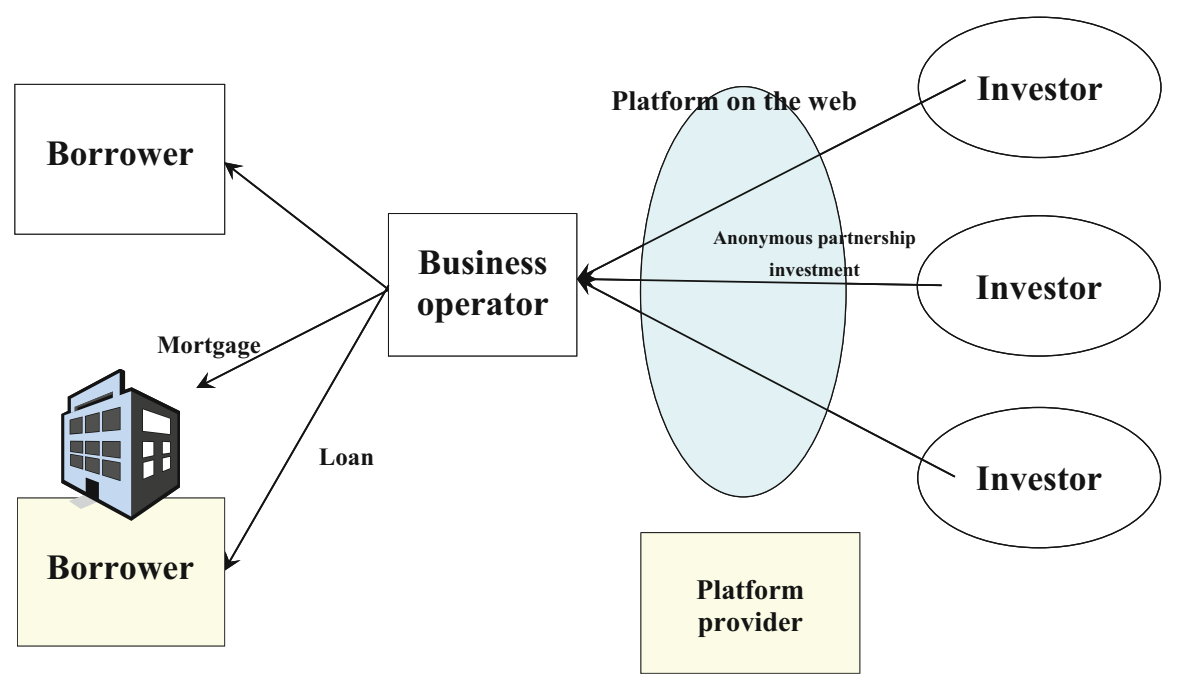

Fig. 21.4 Social Lending Structure in Japan

(i) Approval and authorization

Platform providers (=intermediaries) handle private placements for anonymous partnership (Tokumei-Kumiai) investment as a business and are required to be registered as a Type II Financial Instruments Business. ${ }^{25}$

Business operators (=business operators and lenders) that conduct private placements (self-offering) ${ }^{26}$ of anonymous partnership (Tokumei-

\footnotetext{
${ }^{25}$ Article 2, paragraph (8), item (ix) of the Financial Instruments and Exchange Act.

${ }^{26}$ Article 2, paragraph (8), item (vii) of the Financial Instruments and Exchange Act.
} 
Kumiai) investment interest must essentially be registered as Type II Financial Instruments Business, yet registration is not required if they entrust the handling of private placements to platform providers that are Type II Financial Instruments Business Operator. In addition, in principle, registration as a money lender is required as it is in the business is lending. ${ }^{27}$ However, it is not regarded a money lender if lending is only to its own subsidiaries, etc. ${ }^{28}$

Investors are not required particular approval and authorization. However, it appears that administrative agencies point out concerns about the substantive financial judgment of the investor if the borrower of the loan for the target investment is identified (therefore, the Money Lending Business Act applies to the investor). On this point, in practice, measures seem to be taken where the borrower of the business operator's loan is anonymized, the loans are handled as if multiple loans. Certainly, one of the intentions of requiring lenders to be registered as money lenders under the Money Lending Business Act is to regulate the collection activities of the lenders toward the borrowers. So from that perspective the request for practical fulfillment of such regulation even for investors in social lending might as well be recognized. However, even in the case of investment instruments like securitized loan claims, for example, there are also other investment instruments where the borrowers are identified, so requiring anonymization of borrowers and multiple loans for social lending appears to be excessive regulation from the perspective alone of such intent. Rather, from the perspective of information disclosure to investors, it would be better to solicit investment after identifying the borrower and the target real estate. In addition, it is also pointed out that there have been examples ${ }^{29}$ of inappropriate explanations and operations regarding the borrowers and the use of funds.

(ii) Possibility of issuing documents via electromagnetic means

Unlike the Act on Specified Joint Real Estate Ventures, the Financial Instruments and Exchange Act already permits the issuance of documents before and when executing a contract by electromagnetic means with the consent of investors. ${ }^{30}$

\footnotetext{
${ }^{27}$ Article 2, paragraph (1) of the Money Lending Business Act.

${ }^{28}$ Article 2, paragraph (1), item (v) of the Money Lending Business Act, Article 1-2, item (vi) of the Order for Enforcement of the Money Lending Business Act.

${ }^{29}$ The results of the investigation of Minnano Credit Co., Ltd. by the Securities and Exchange Surveillance Commission was the recommendation of administrative procedures, which was an example of administrative procedures from the Kanto Local Finance Bureau (order to suspend operations for 1 month, and operation improvement order).

${ }^{30}$ Article 37-4, paragraph (2), Article 37-5, paragraph (2), Article 34-2, paragraph (4) of the Financial Instruments and Exchange Act; Article 56 of the Cabinet Office Order on Financial Instruments Business, etc.
} 
(iii) Number of people requirement for offering and solicitation

Unless an anonymous partnership (Tokumei-Kumiai) investment interest invests more than $50 \%$ of raised funds in a securities investment, it is not subject to disclosure regulation (in the main paragraph of Article 3, item (iii) of the Financial Instruments and Exchange Act, collective investment scheme interest (rights listed in Article 2, paragraph (2), item (v)) is not subject to disclosure regulation, while in the provisions of Article 3, item (iii) and only those that are mainly invested in securities are subject to disclosure regulation as an exception). Therefore, even in the case of offering and solicitation for more than 500 investors, this does not correspond to a public offering, and there is no need for a securities registration statement. However, in the case of 500 or more investors, the documents to be delivered before concluding contracts must be submitted to the Prime Minister in advance. ${ }^{31}$

\subsubsection{Future Issues}

1. Grant of Benefits, etc. other than Economic Considerations

Crowd funding, which is a scheme for collecting small amounts of funds from a large number of multiple individuals, is a mechanism that is fit not just for the purpose of pure yield but for soliciting funds from supporters and fans for some sort of business and purpose.

On this point, for example, the service provided by large American crowd funding companies include the grant of non-economic compensation benefits such as special discounts to investors as "owners" of the hotel or restaurant to be developed, ${ }^{32}$ and the test marketing functions prior to the formal commencement of the project to developers ${ }^{33}$ in addition to the purpose of pure yield or for the procurement of funds.

In this way, in Japan, too, in the context of cultivating regional areas and regional activation as well as the use of public real estate, even when a property or project could not necessarily be considered highly profitable, for example, there is expected to be funds that will provide returns in the form of "return + alpha" for those individuals who are from the region or who are motivated to contribute funds for non-yield return purposes such as users or potential users of the services (medical services, childcare services, etc.) of such real estate (Fig. 21.5).

\footnotetext{
${ }^{31}$ Article 37-3, paragraph (3) of the Financial Instruments and Exchange Act, Article 16-2 of the Order for Enforcement of the Financial Instruments and Exchange Act.

32،"RealtyMogul" (https://www.realtymogul.com/).

33"FUNDRISE" (https://fundrise.com/)). Note that FUNDRISE reportedly raised $\$ 2.5$ billion through crowd funding as part of the funds to develop the 3 World Trade Center development project in the United States.
} 

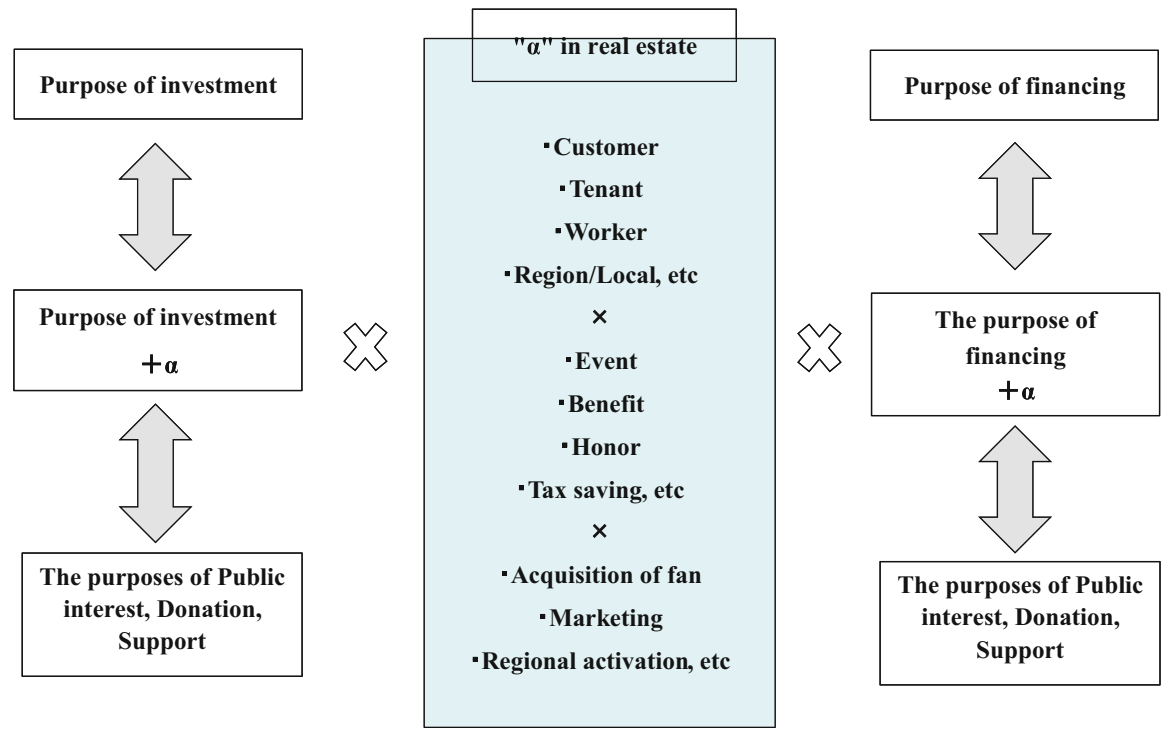

Fig. 21.5 Benefits, etc. other than Economic Considerations

2. Procedures for identification in accordance with the Act on Prevention of Transfer of Criminal Proceeds

The business operator who operates Specified Joint Real Estate Ventures in accordance with the Act on Specified Joint Real Estate Ventures and Type II Financial Instruments Business Operators who are platform providers for social lending correspond to business operators that are identified in the provisions of the Act on Prevention of Transfer of Criminal Proceeds. Therefore, their transactions relating to the operations for the respective crowd funding when conducted between investors require confirmation of identity in accordance with the Act on Prevention of Transfer of Criminal Proceeds. ${ }^{34}$

On this point, in case of non-face-to-face transactions with individuals conducted via the Internet, the method for confirming identity shall, except for the method using digital certificates, ${ }^{35}$ be either the method of forwarding transaction documents, to the address of the individual mentioned in the identity documents by non-transferable postal mail that must be returned when undeliverable, such as registered mail, or the method of sending transaction

\footnotetext{
${ }^{34}$ Article 2, paragraph (2), item (xxi) and item (xxvi) of the Act on Prevention of Transfer of Criminal Proceeds; Article 6, item (i) and item (x), and Article 7, paragraph (1), item (i), (i) and (m) of the Order for Enforcement of the Act on Prevention of Transfer of Criminal Proceeds.

${ }^{35}$ Article 6, paragraph (1), item (i), (g), (h) and (i) of the Ordinance for Enforcement of the Act on Prevention of Transfer of Criminal Proceeds.
} 
documents that can only be delivered to the person him or herself, ${ }^{36}$ and it is vital that this exchange occur offline.

Completing all the procedures via the Internet is considered desirable for crowd funding, which is a scheme of collecting very small amounts of funds from a large number of multiple individuals. In addition, when investigating the possibility of soliciting the contribution of funds from overseas investors in crossborder transactions, there is no denying that the current confirmation of identity procedures in accordance with the Act on Prevention of Transfer of Criminal Proceeds could be a cause of obstruction and we hope that there will be future revisions that include exemptions according to the amount of funds, etc.

3. Investment and distribution through cryptocurrencies

For anonymous partnership (Tokumei-Kumiai) investment type Specified Joint Real Estate Ventures and for social lending, there is an assumption that the investment will be made by "cash or other property.",37

On this point, although the discussion on the legal nature of so-called cryptocurrencies such as Bitcoin remains unsettled, it is highly likely that they could correspond to "property." 38 In that case, there could conceivably be funds that are invested using cryptocurrencies with the profit distributed using cryptocurrencies. Furthermore, in that case, it would theoretically be possible to constitute distributed or autonomous real estate funds on the Internet that use smart contracts via blockchain technology. Urgent investigation is required concerning the case of transactions that use such cryptocurrencies not only from their legal treatment but how they should be treated for accounting and tax purposes and whether or not there is a withholding tax obligation.

4. Data analysis and analytical service

There are services that analyze stores by applying artificial intelligence to existing data such as POS and in-store data such as the number of customers and the stay dynamics that can be obtained by analyzing images from multiple cameras installed in the store for the purpose of increasing sales and reducing costs. $^{39}$

5. Service to improve the efficiency of operations

There are service types provided to real estate operators that improve the efficiency of operations such as real estate property information filtering service

\footnotetext{
${ }^{36}$ Article 6, paragraph (1), item (i), (b), (e) and (f) of the Ordinance for Enforcement of the Act on Prevention of Transfer of Criminal Proceeds.

${ }^{37}$ Article 2, paragraph (2), item (i) of the Act on Specified Joint Real Estate Ventures, Article 535 and Article 536, paragraph (2) of the Commercial Code.

${ }^{38}$ Yoshihiro Kataoka "Regulation and legal issues for cryptocurrency (Vol 1.)" NBL No. 1076 (2014), page $58+$, etc.

39،ABEJA Platform” (https://service.abeja.asia/).
} 
(information browsing and service to improve the efficiency of management

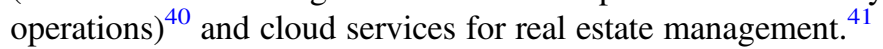

6. Virtual reality (VR) technology

VR technology and real estate are thought to have comparatively high affinity. For example, there are services ${ }^{42}$ that make it possible to view the state of a vacant plot of land and a property under construction as if the property that is planned has already been constructed as well as displaying the view from the balcony or verandah.

\subsection{Legal Issues Concerning Information and Big Data}

When compared to the United States and elsewhere, the current Japanese real estate secondary market is noted as being inadequate in terms of the system of registration, disclosure, and utilization of real estate price information, property information, and transaction information, such as the Real Estate Information Network System (REINS).

On this point, each business operator that attempts to evaluate real estate values using AI, etc. would utilize enormous sample data by analyzing the property information that it has independently accumulated and obtained other than what is publicly available.

The following investigates the legal issues in using and obtaining such property information.

\subsubsection{The Act on the Protection of Personal Information ${ }^{43}$}

"Personal Information" is the information relating to a living individual that can identify the specific individual by name, date of birth, or other descriptions contained in such information (including such information as will allow easy reference to other information and will thereby enable the identification of the specific individual) or something that includes an individual identification code ${ }^{44}$ in (1) or (2) below.

\footnotetext{
40“data terminal" (https://terminals.jp/product/dataterminal.html).

41 "Property Databank" (https://www.propertydbk.com/).

42“Miraie 360" (https://miraie-net.com/360/?utm_source=yahoo\&utm_medium =cpc\&utm_ campaign=360) "FINE"

(http://www.fine-d.co.jp/service/housingvr.html). "SHOWRISE" (https://oh.openhouse-group. com/company/news/news20160527.html), etc.

${ }^{43}$ Revised law enacted May 30, 2017.

${ }^{44}$ Article 2, paragraph (1) of the Act on the Protection of Personal Information.
} 
1. Codes into which a bodily partial feature of the specific individual has been converted in order to be provided for use by computers.

2. Codes which are differently assigned in regard to the use of services provided to an individual, to the purchase of goods sold to an individual, or to the documents issued to an individual.

If information data that includes Personal Information is to be used in the development of AI by applying such information or data, or sold as a data set to a third party, it should be subject to the restriction of the purpose of the use or of the provision to third parties in accordance with the Act on the Protection of Personal Information. $^{45}$

On this point, the Revised Act, enacted on May 30, 2017, introduced the concept of "Anonymously Processed Information" for the purpose of enabling the utilization of Big Data. Anonymously Processed Information means information relating to an individual that can be produced from processing Personal Information so as neither to be able to identify a specific individual nor to be able to restore the Personal Information. ${ }^{46}$ The specific processing method should be in accordance with the "Guidelines on the Act on the Protection of Personal Information (Anonymously Processed Information)" released by the Personal Information Protection Commission.

The use of Anonymously Processed Information and its provision to third parties does not require individual consent pertaining to the raw Personal Information, so it is expected that the utilization of Big Data will be promoted.

\subsubsection{Contractual Obligation of Confidentiality and Restrictions on the Purpose of Use}

There could be a problem with the use of information even if it does not correspond to "Personal Information" under the Act on the Protection of Personal Information if such information is obtained for a transaction based on some form of contract and there is an obligation of confidentiality such as the prohibition of disclosure of such information to a third party or restriction on the purpose of use, if such information is used or provided to a third party in breach of such obligation of confidentiality.

This point is ultimately a problem of interpretation of the contract which makes it difficult to judge if there is a breach of the obligation of confidentiality due to uniform interpretation and operation. However, my personal opinion is that in the case of such information that is processed in the similar way to Anonymously Processed Information and cannot be traced back to identify the raw property or

\footnotetext{
${ }^{45}$ Article 16, paragraph (1) and Article 23, paragraph (1) of the Act on the Protection of Personal Information.

${ }^{46}$ Article 2, paragraph (9) of the Act on the Protection of Personal Information.
} 
the relevant party, there could be scope to interpret such information as being outside the scope of application of the obligation of confidentiality in relation to the use of such information or the provision to a third party following such process.

Of course, the judgment of legality ultimately depends on the courts, but it is hoped that the authorities present certain interpretative guidelines from the perspective of promoting the utilization of real estate property information.

\subsubsection{Crawling}

Crawling refers to a program that patrols websites on the Internet and automatically collects an enormous volume of data by duplicating and saving the information on each website. Real estate property information on the Internet can be collected through such crawling.

In terms of the legality of such crawling, first, in the case of information and data that is automatically collected and deemed to be works protected under the Copyright Act, duplication without permission is illegal. In addition, in certain cases, such information and data could also be protected as a trade secret in accordance to the Unfair Competition Prevention Act.

However, for example, in the case of information and data sets that are not specifically approved as intellectual creations ${ }^{47}$ and such that information and data are widely available to the general public on the Internet, it will not correspond to either a copyrighted work or a trade secret. Even in such case, whether there is legal restriction on crawling will in certain cases result in crawling itself being an illegal behavior, and a claim for damages could be approved. ${ }^{48}$ In my personal opinion, this possibility cannot be denied.

The judgment on the legality of crawling will ultimately depend on the judgment of individual specific court cases, but from the perspective of promoting the utilization of real estate property information, we expect the authorities to present certain interpretative guidelines from the perspective of promoting the utilization of real estate property information.

\footnotetext{
${ }^{47}$ Apart from the case of being recognized as an intellectual creation as a literary work (Article 10, paragraph (1), item (i) of the Copyright Act), there is also the case of database works (Article $12-2$ of the Copyright Act) as an intellectual creation for the selection or systematic construction of information.

${ }^{48}$ Tatsuhiro Ueno "Legal Protection of Automatically Collected Big Data," Patent Vol. 70 No.2 (2017), page 33 .
} 


\subsection{Conclusion}

We could say that Real Estate Tech services in Japan are still in their dawning stage, but the main underlying trend is undeniably one whereby services and operations are being developed that will surpass common practice within the traditional real estate industry through use of the Internet, other ICT technology and AI, and such other programs. So the next issue will be the speed of such development and permeation. The main contributing factor to such speed will be the extent to which the thinking and attitudes of existing real estate operators (i.e., of the people in the industry, in particular, major business operator) take the initiative in confronting Real Estate Tech, and the issue of sorting out the environment (including the legal system and interpretation), such as the problem of collecting information and data such as real estate property information. In the future, business operators from other industries and overseas business operators could enter the domestic real estate market, and both real estate business operators and the governmental authorities will need to move rapidly to deal with such a situation.

Open Access This chapter is licensed under the terms of the Creative Commons Attribution 4.0 International License (http://creativecommons.org/licenses/by/4.0/), which permits use, sharing, adaptation, distribution and reproduction in any medium or format, as long as you give appropriate credit to the original author(s) and the source, provide a link to the Creative Commons licence and indicate if changes were made.

The images or other third party material in this chapter are included in the chapter's Creative Commons licence, unless indicated otherwise in a credit line to the material. If material is not included in the chapter's Creative Commons licence and your intended use is not permitted by statutory regulation or exceeds the permitted use, you will need to obtain permission directly from the copyright holder.

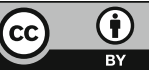

